\title{
Efek Inkubasi Aerob Fakultatif terhadap Kualitas Organoleptik, Fisik, dan Nutrisi Ampas Tahu Difermentasi Kapang Neurospora sitophila dan Trichoderma viridae sebagai Pakan Ternak
}

\section{Effects of Facultative Aerobic Incubation on Organoleptic Quality, Physical and Nutrition Tofu Dregs Fermentation by Kapang Neurospora sitophila and Trichoderma viridae as Animal Feed}

\author{
Budiyanto $^{1 *}$, W. Suryapratama ${ }^{2}$, dan S. Rahayu ${ }^{2}$ \\ ${ }^{1}$ Program Magister, Fakultas Peternakan, Universitas Jenderal Soedirman, Purwokerto - Indonesia \\ ${ }^{2}$ Fakultas Peternakan, Universitas Jenderal Soedirman, Purwokerto - Indonesia \\ *Corresponding E-mail: boedyyanto83@gmail.com \\ (Diterima: 17 November 2020; Disetujui: 3 Maret 2021)
}

\begin{abstract}
ABSTRAK
Ampas tahu memiliki kandungan nutrien tinggi dan telah lama dimanfaatkan sebagai bahan pakan ternak, namun ampas tahu memiliki kekurangan yaitu daya simpan yang singkat sehingga diperlukan teknologi fermentasi. Fermentasi menggunakan kapang Neurospora sitophila (NS) dan Trichoderma viridae (TV) diharapkan menjadi solusi terkait permasalahan tersebut. Penelitian menggunakan teknik fermentasi aerob fakultatif, metode penelitian Rancangan Acak Lengkap 6 perlakuan diulangan 4 kali, Pengamtan Organoleptik, kualitas Fisik dan Kualitas Nutrient produk fermentasi. Kombinasi lama fermentasi 0,4,8 hari (B1,B2,B3) dan jenis kapang yaitu Neurospora sitophila (A1) dan Trichoderma viridae (A2). Analisis data dengan uji F, apabila berpengaruh nyata dilanjutkan Uji Duncan Multiple Test (DMRT) taraf 5\%. Terdapat Interaksi dari pengunaan kapang dan lama fermentasi terhadap suhu akhir, terdapat Interaksi dari pengunaan kapang dan lama fermentasi terhadap derajat keasaman $\mathrm{pH}$ akhir, terdapat Interaksi antara lama fermentasi terhadap warna sebelum dikeringkan, Terdapat Interaksi dari pengunaan kapang dan lama fermentasi terhadap warna setelah dikeringkan, Terdapat Interaksi dari pengunaan kapang dan lama fermentasi terhadap tekstur sebelum dikeringkan, terdapat interaksi dari jenis kapang dan waktu lama fermentasi terhadap Tekstur setelah dikeringkan, Terdapat interaksi dari pengunaan jenis kapang dan waktu lama fermentasi terhadap Aroma setelah dikeringkan. Ampas tahu yang difermentasi menggunakan kapang Neurospora sitophila selama 8 hari menghasilkan produk terbaik sebagai bahan pakan konsentrat.

Kata kunci: kapang, fermentasi, ampas tahu, organoleptik, kualitas fisik
\end{abstract}

\section{ABSTRACT}

Tofu dregs have high nutrient content and have long been used as animal feed ingredients, but tofu dregs have shortcomings, namely short shelf life, so fermentation technology is needed. Fermentation using Neurospora sitophila (NS) and Trichoderma viridae (TV) is expected to solve these problems. The research used a facultative aerobic fermentation technique, a completely randomized design six treatments repeated four times, Organoleptic treatment, physical quality, and nutritional quality of fermented products. The combination of fermentation time of 0.4 .8 days $(B 1, B 2, B 3)$ and types of fungi are Neurospora sitophila (A1) and Trichoderma viridae (A2). The data were analyzed using the F test; if it has a significant effect, it is followed by the Duncan Multiple Range Test (DMRT) at the 5\% level. There is an interaction between the use of mold and the duration of fermentation against the final temperature; there is an interaction in the use of mold and the duration of fermentation to the degree of acidity of the final $\mathrm{pH}$; there is an interaction between the duration of fermentation and the color before drying, There is an interaction in the use of mold and the length of fermentation on color After drying, there is an interaction in the use of mold and the length of fermentation on the texture before drying, there is an interaction in the type of mold and the length of time for fermentation to the texture after drying, there is an interaction in the use of the type of mold and 
the long time for fermentation to the aroma after drying. Tofu dregs fermented using Neurospora sitophila for eight days produced the best product as a concentrate feed ingredient.

Keywords: mold, fermentation, tofu dregs, organoleptic, physical quality

\section{PENDAHULUAN}

Pakan merupakan aspek yang penting dalam bidang peternakan, kualitas pakan sangat mempengaruhi produktivitas dari ternak, bahan pakan yang berkualitas pasti akan menghasilkan pakan ternak yang berkualitas. Menurut Acmadi (2007), untuk menentukan bahan pakan perlu mempertimbangkan halhal berikut kandungan nutrisi, kualitas fisik dan organoleptik bahan pakan yang dipakai. Aspek-aspek yang perlu diperhatikan dalam menyusun ransum pakan yaitu: ketersediaan bahan baku, standar nutrien dari ternak sendiri, teknik pengolahan, formulasi, teknik pencampuran dan kontaminasi. Aspek terkait ketersediaan, penanganan, karaketeristik dari suatu bahan pakan berperan penting dalam penyusunan formulasi pakan ternak dengan kulitas dan mutu yang tinggi.

Tingkat konsumsi ternak dipengaruhi beberapa faktor antar lain: penampilan, bentuk pakan, aroma, rasa, tekstur dan suhu lingkungan. Kualitas tekstur, warna, aroma dan rasa yang disukai ternak menunjukkan kualitas pakan yang sangat baik sehingga berpengaruh terhadap palatabilas ternak (Christi et al., 2018).

Ampas tahu merupakan hasil sampingan dari olahan industri kedelai menjadi tahu, ampas tahu memiliki nilai nutrisi yang dapat dimanfaatkan sebagai pakan ternak tetapi memiliki kekurangan yaitu kadar air yang tinggi sehingga menyebabkan cepat rusak. Kandungan ampas tahu dapat digunakan sebagai bahan pakan dengan kandungan protein (16-24\%), TDN $21-24 \%$ dan karbohidrat (52-56\%) (Li et al., 2013; Kanti, 2017). Ampas tahu dari limbah industri tahu kedelai, memiliki kadar air tinggi, kandungan TDN rendah, protein yang rendah serta kadar serat tinggi. Hal ini menyebabkan penggunaan ampas tahu untuk bahan baku konsentrat masih perlu ditingkatkan kualitasnya.

Fermentasi merupakan teknologi pengawetan yang biasa dipergunakan dan mudah diaplikasikan dimasyarakat, serta proses yang relatif mudah dan singkat. Fermentasi merupakan aplikasi metabolisme mikroba untuk mengubah bahan baku menjadi produk yang bernilai lebih tinggi baik dari kualitas fisik maupun nutriennya (Lestari, 2001). Fermentasi memiliki keunggulan yaitu dapat menghilangkan bau, meningkatkan daya cerna, menghilangkan daya racun dan menghasilkan warna yang diinginkan. Mikroba yang banyak digunakan sebagai inokulum fermentasi adalah kapang. Pertumbuhan kapang mudah dilihat karena penampakannya yang berserabut seperti kapas berwarna putih (Sukarminah et al., 2008).

Kapang Neurospora sitophila (N. sitophila) adalah kapang karotenogenik yang menghasilkan enzim yaitu selulase, fitase, protease dan amilase yang termasuk kelompok generated as safe (GRAS) (Kanti, 2017). Kapang Trichoderma viridae (T. viridae) merupakan kapang saprophyt, kapang ini menghasilkan enzim selulase kompleks. Enzim tersebut mempunyai kemampuan untuk menghidrolisa total selulosa murni yang tidak dapat larut menjadi glukosa. Penguraian selulosa menjadi glukosa akan meningkatkan populasi mikroba terutama yang bersifat selulolitik (Aisjah, 2001).

Atas dasar daya simpan ampas tahu yang pendek dan kandungan serat kasar tinggi perlu dilakukan penelitian untuk menghasilkan produk ampas tahu yang memiliki kualitas lebih bagus dan daya simpan lama.

Tujuan penelitian mengkaji metode inkubasi fakultatif serta waktu fermentasi terbaik dari penggunaan kapang $N$. sitophila dan $T$. viridae pada sampas tahu ditinjau dari Kualitas Organoletip (suhu dan $\mathrm{pH}$ ) serta 
Kualitas Fisik (warna sebelum dikeringkan, warna setelah dikeringkan, tekstur sebelum dikeringkan, aroma sebelum dikeringkan dan tekstur sesudah dikeringkan) dan Kualitas Nutrisi.

\section{METODE PENELITIAN}

\section{Materi Penelitian}

Bahan yang digunakan dalam penelitian fermentasi ampas tahu adalah; Ampas tahu, kapang $N$. sitophila dan kapang $T$. viridae.

\section{Alat}

Alat yang digunakan dalam penelitian fermentasi ampas tahu adalah timbangan, oven pengering, $\mathrm{pH}$ meter, thermometer digital, pengepres, karung plastik, terpal, tong dan peralatan analisis proksimat.

\section{Rancangan Percobaan}

Rancangan Acak Lengkap pola Faktorial 6 perlakuan diulang 4 kali sehingga diperoleh 24 unit percobaan. Perlakuan ampas tahu menggunakan 2 jenis kapang yaitu kapang $N$. sitophila dan $T$. viridae dengan lama waktu fermentasi yaitu $0,4,8$ hari. Analisis data dengan uji $\mathrm{F}$, apabila berpengaruh nyata dilanjutkan dengan Uji Duncan Multiple Test (DMRT) taraf 5\%. Peubah yang diukur dan diamati yaitu warna, bau, suhu, $\mathrm{pH}$, tekstur dan nutrisi (BK, SK, PK, LK, abu, dan BETN) (AOAC, 1995). Pengamatan ini dilakukan sebelum (awal) dan sesudah (akhir) proses fermentasi. Dari penelitian akan disimpulkan perlakuan yang bisa dipakai sebagai bahan pakan.

Metode dan prosedur untuk mengukur kualitas organoleptic dan fisik sebagai berikut:

1. Pengukuran Suhu mempergunakan thermometer digital diletakkan pada substrat sebelum plastik penutup/Wrap terbuka dan ditunggu 60 detik.

2. Pengukuran $\mathrm{pH}$ menggunakan $\mathrm{pH}$ meter dengan cara mengencerkan produk dengan aquades hal tersebut dikarenakan substrat berbentuk semi padat sedangka $\mathrm{pH}$ meter yang dipakai hanya bisa membaca pada substart yang cair.

3. Pengamatan warna sebelum dikeringkan menggunakan 15 panelis, pengisian skoring warna dengan memberi penilaian pada tabel yang telah disiapkan (Tabel 1).

Tabel 1. Panduan pengisian skor warna sebelum dikeringkan

\begin{tabular}{cc}
\hline Skoring & Keterangan Tekstur \\
\hline 1 & Hitam \\
2 & Coklat \\
4 & Abu-abu \\
5 & Putih bersih \\
\hline
\end{tabular}

4. Pengamatan warna setelah dikeringkan. Dalam penelitian ini proses pengeringan dilakukan dengan menggunakan oven dengan pengaturan suhu $60^{\circ} \mathrm{C}$ dikarenakan produk rata-rata mengandung kadar air cukup tinggi $70 \%$ pengeringan dengan oven dilakukan selama 3 hari. Pengisian skoring warna dengan memberi penilaian pada tabel yang telah disiapkan dengan panduan pengisian (Tabel 2).

Tabel 2. Panduan pengisian skor warna setelah dikeringkan

\begin{tabular}{cc}
\hline Skoring & Keterangan Warna \\
\hline 1 & Putih bersih \\
2 & Abu-abu \\
4 & Coklat \\
5 & Coklat Tua \\
\hline
\end{tabular}

5. Pengamatan Tekstur sebelum dikeringkan menggunakan 15 panelis. Cara pengamatan tekstur yaitu menyentuh langsung produk fermentasi dengan jarijari dan memasukkan skor sesuai panduan yang ada (Tabel 3).

6. Dalam pengamatan Tekstur setelah dikeringkan menggunakan 15 panelis panduan pengisian skor tekstur sesudah dikeringkan (Tabel 4).

7. Dalam pengamatan Aroma sesudah dikeringkan menggunakan 15 panelis panduan pengisian skor (Tabel 5). 
Tabel 3. Panduan pengisian skor Tekstur sebelum dikeringkan

\begin{tabular}{cl}
\hline Skoring & Keterangan Tekstur \\
\hline 1 & Kering \\
2 & $\begin{array}{l}\text { Agak kering (tidak menggumpal } \\
\text { dan remah) }\end{array}$ \\
4 & $\begin{array}{l}\text { Agak basah (menggumpal dan } \\
\text { remah) }\end{array}$ \\
5 & Basah (mengumpal dan berair) \\
\hline
\end{tabular}

Tabel 4. Panduan pengisian skor Tekstur sesudah dikeringkan

\begin{tabular}{cl}
\hline Skoring & Keterangan Tekstur \\
\hline 1 & $\begin{array}{l}\text { Agak basah (menggumpal dan } \\
\text { remah) }\end{array}$ \\
2 & $\begin{array}{l}\text { Agak kering (tidak menggumpal } \\
\text { dan remah) }\end{array}$ \\
4 & Kering remah \\
5 & Kering keras \\
\hline
\end{tabular}

Tabel 5. Panduan pengisian skor Aroma sesudah dikeringkan

\begin{tabular}{cl}
\hline Skoring & Keterangan Tekstur \\
\hline 1 & Ampas Tahu Netral \\
2 & Apek \\
4 & Sangat khas fermentasi \\
5 & $\begin{array}{l}\text { Sangat khas fermentasi } \\
\text { menyengat }\end{array}$ \\
\hline
\end{tabular}

\section{HASIL DAN PEMBAHASAN}

\section{Pengamatan Organoleptik}

\section{a. Suhu akhir fermentasi}

Hasil analisis variansi disimpulkan terdapat interaksi penggunaan kapang dan lama inkubasi terhadap suhu akhir $\mathrm{P}<0,05$. Rata-rata pada perlakuan Kapang N. sitophila suhunya $26,14^{\circ} \mathrm{C}$ dan $T$. viridae suhunya $25,58^{\circ} \mathrm{C}$, hal tersebut kemungkinan proses fermentasi yang dilakukan secara aerob fakultatif, ketebalan substrat tidak lebih dari $2 \mathrm{~cm}$ dan udara dapat masuk kedalam lingkungan fermentasi terbatas. Menurut Noverina (2008), menerangkan bahwa $\mathrm{N}$ Sithopila termasuk kapang mesophilik yang memiliki suhu optimum pertumbuhan sekitar $30^{\circ} \mathrm{C}$. Sedangkan untuk kapang $T$. Viridae berkisar pada suhu $25,58^{\circ} \mathrm{C}$ hal tersebut sesuai pendapat dari Purwati (2018) yang menerangkan dalam penelitiannya suhu untuk kapang T. viridae Suhu optimum pertumbuhan sekitar $25-28^{\circ} \mathrm{C}$.

\section{b. pH Akhir}

Hasil analisis variansi disimpulkan terdapat interaksi penggunaan kapang dan lama inkubasi terhadap derajat keasaman $\mathrm{pH}$ produk fermentasi $\mathrm{P}<0,05$ dengan rerata pH. Perlakuan N. sitophila 6,44 sedangkan $T$. viridae $\mathrm{pH} 8,23$. Hal tersebut sesuai pendapat Noverina (2008) menyatakan kapang $N$. sitophila termasuk kapang mesophilik yang memiliki pH antara 4,5 - 6,5. pH kapang $N$. sithopila dengan perlakuan lama waktu inkubasi memberi pengaruh yang mana semakin lama waktu inkubasi menyebabkan penurunan $\mathrm{pH}$ dengan rat-rata $\mathrm{pH} 6$, fermentasi dengan kapang $N$. sitophila yang cenderung merombak protein ampas tahu menjadi glukosa Perlakuan T. viridae cenderung stabil $\mathrm{pH}$ yaitu dengan rata-rata 8 , kapang $T$. viridae dengan lama inkubasi tidak berpengaruh terhadap perubahan $\mathrm{pH}$ yaitu $\mathrm{pH}$ 8, hal tersebut kemungkinan dipengaruhi oleh teknik fermentasi apabila dilakukan dengan minim oksigen atau fakultatif akan menyebabkan suasana menjadi asam. Menurut Kanti (2017) faktor $\mathrm{pH}$ berpengaruh terhadap pertumbuhan biomassa dan produksi enzim fitase. Produksi fitase untuk kapang neurospora dapat aktif pada suasana $\mathrm{pH}$ 6. Pamungkas (2011) yang menyatakan kapang $T$. viridae hidup pada rentang $\mathrm{pH}$ 4-8.

\section{Pengamatan Kualitas Fisik}

\section{a. Warna sebelum dikeringkan}

Hasil analisis variansi disimpulkan terdapat interaksi penggunaan kapang dan lama inkubasi terhadap produk fermentasi terkait warna sebelum dikeringkan $\mathrm{P}<0,05$. Pengamatan langsung menunjukkan spesifikasi warna untuk produk dari kapang $N$. sitophila putih untuk $T$. viridae juga abu-abu, hal tersebut dikarenakan inkubasi fakultatif 
menyebabkan miselium tidak mudah terkena udara bebas dan warna dapat stabil abu-abu. Hal tersebut sesuai pendapat dari (Novianti, 2012) menerangkan Produksi $\beta$-karoten akan meningkat seiring dengan lama fermentasi Menurut Novianti (2012), menjelaskan perubahan warna terbentuk karena adanya rangsangan cahaya, adanya pengaruh udara, dan sinar matahari. Kapang $T$. viridae pertumbuhan kapang baru dimulai pada hari ke-5 sehingga tidak akan memberikan warna yang signifikan. Kapang T. viridae pertumbuhan kapang baru dimulai pada hari ke-5 sehingga tidak akan memberikan warna yang mulai berubah. Menurut Beuchat (1977) kapang $T$. viridae akan terlihat bermiselium kusam.

\section{b. Warna setelah dikeringkan}

Hasil analisis variansi disimpulkan terdapat interaksi penggunaan kapang dan lama inkubasi terhadap warna setelah dikeringkan $\mathrm{P}<0,05$. Pengamatan langsung menunjukkan spesifikasi warna untuk produk dari kapang $N$. sitophila coklat sedangkan untuk T. viridae abu-abu. Perubahan warna pada produk fermentasi dipengaruhi oleh udara bebas, suhu dan cahaya, substart yang difermentasi kapang $N$. sitophila apabila telah selesai waktu inkubasi segera dibuka dan dikeringkan maka akan terjadi perubahan warna yang awalnya berwarna putih setelah mengalami proses pengeringan maka akan berubah menjadi coklat apabila inkubasi lebih dari 4 hari, sedangkan pada produk yang difermentsi dengan kapang $T$. viridae perubahan produk setelah dikeringkan akan berubah menjadi sedikit hijau atau abu-abu hal tersebut dikarenakan trichoderma cenerung mengubah warna abu-abu.

Masing-masing kapang dengan lama inkubasi memberi perubahan yang berbeda kapang $N$. sitophila cenderung memberi warna krem, jingga sampai coklat sedangkan kapang $T$. viridae memberi warna yang relatif stabil yaitu hijau muda. Seperti pernyataan Nurfaizin (2015), N. sitophila menghasilkan pigmen karotenoid, karakteristik konidianya berwarna kuning hingga jingga karena mengandung senyawa karoten. Sedangkan Judoamidjojo et al. (1992), menyatakan bahan pakan terfermentasi menghasilkan warna sesuai dengan asalnya. Menurut Christi et al. (2018), menyatakan warna yang baik akan menghasilkan pula aroma yang baik pula.

\section{c. Tekstur sebelum dikeringkan}

Hasil analisis variansi disimpulkan terdapat interaksi penggunaan kapang dan lama inkubasi terhadap tekstur sebelum dikeringkan $\mathrm{P}<0,05$. Pengamatan secara langsung diketahui dengan spesifikasi tekstur $N$. sitophila basah (menggumpal dan berair) sedangkan $T$. viridae agak basah (mengumpal dan remah). Kapang $N$. sitophila cenderung menghasilkan produk yang bersifat basah dan berair hal tersebut dimungkinkan karena substrat ampas tahu sendiri masih sangat basah dengan kadar air waktu fermentasi mencapai $50 \%$ sedangkan hasil fermentsi dengan menggunakan $T$. viridae bertekstur basah dan sedikit berair. Menurut Telew (2013), semakin sedikit kandungan air dari bahan akan dihasilkan tekstur produk fermentasi yang sedikit kering bahkan kering sekali, sebaliknya jika kandungan air tinggi maka dihasilkan tekstur yang agak basah. Menurut Leng (1991), proses fermentasi menghasilkan tekstur yang berbeda tergantung dari jenis bahan yang digunakan, kering atau tidaknya hasil fermentasi tergantung pada kadar air bahan. Menurut Novianti (2012), pembentukan spora dalam jumlah besar terjadi pada masa pertumbuhan statis antara 5 dan 7 hari fermentasi pada kapang $N$. sitophila. Menurut Widiastuti (2013), bahwa kualitas tekstur dipengaruhi oleh kadar air dan serat kasar, pakan yang mengandung serat kasar tinggi akan membuat tekstur menjadi kasar.

\section{d. Tekstur sesudah dikeringkan}

Hasil analisis variansi disimpulkan terdapat interaksi penggunaan kapang dan lama inkubasi terhadap tekstur setelah dikeringkan $\mathrm{P}<0,05$. Tekstur setelah dikeringkan menyatakan bahwa dengan spesifikasi tekstur $N$. sitophila kering 
Tabel 6. Analis Proksimat Produk

\begin{tabular}{clccccccc}
\hline \multirow{2}{*}{ No } & \multirow{2}{*}{ Kode Sampel } & \multirow{2}{*}{ Air (\%) } & \multirow{2}{*}{ BK (\%) } & \multicolumn{7}{c}{$\%$ BK } \\
\cline { 5 - 9 } & & & & PK & LK & SK & Abu & BETN \\
\hline A1B1 & 10,17 & 89,83 & 14,73 & 4,40 & 22,04 & 2,85 & 55,99 \\
2 & A1B2 & 9,73 & 90,27 & 24,28 & 9,96 & 14,70 & 4,47 & 46,59 \\
3 & A1B3 & 9,11 & 90,89 & 26,13 & 9,72 & 21,96 & 5,97 & 36,22 \\
4 & A2B1 & 8,86 & 91,14 & 14,87 & 5,11 & 25,80 & 17,22 & 37,01 \\
5 & A2B2 & 3,93 & 96,07 & 15,82 & 3,90 & 31,57 & 24,49 & 24,23 \\
6 & A2B3 & 5,11 & 94,89 & 16,43 & 8,18 & 32,14 & 22,09 & 21,16 \\
\hline
\end{tabular}

Keterangan: $\mathrm{A} 1 \mathrm{~B} 1=N$. sitophila dengan lama waktu fermentasi 0 hari

$\mathrm{A} 1 \mathrm{~B} 2=N$. sitophila dengan lama waktu fermentasi 4 hari

$\mathrm{A} 1 \mathrm{~B} 3=N$. sitophila denganlama waktu fermentasi 8 hari

$\mathrm{A} 2 \mathrm{~B} 1=T$. viridae dengan lama waktu fermentasi 0 hari

A2B2 $=T$ Viridae dengan lama waktu fermentasi 4 hari

A2B3 $=T$ Viridae dengan lama waktu fermentasi 8 hari

keras sedangkan $T$. viridae kering remah. Penggunaan kapang $N$. sitophila dengan lama inkubasi memberi pengaruh terhadap produk yang dikeringkan semakin lama inkubasi berpengaruh terhadap tingkat kekerasan produk, hal tersebut dimungkinkan karena ikatan-ikatan glukosa yang kering sehingga menyebabkan tekstur mengeras, sedangkan untuk produk dari $T$. viridae cenderung memberikan tekstur yang remah. T. viride tidak mampu mendegradasi kandungan hemiselulosa (Hamelinck et al., 2005). Menurut Widiastuti (2013), yang menyatakan bahwa kualitas tekstur dipengaruhi oleh kadar air dan serat kasar pada pakan, pakan yang mengandung serat kasar tinggi akan membuat tekstur menjadi kasar.

\section{e. Aroma setelah dikeringkan}

Hasil analisis variansi disimpulkan terdapat interaksi penggunaan kapang dan lama inkubasi terhadap aroma setelah dikeringkan $\mathrm{P}<0,05$. Hasil pengamatan dilapangan diperoleh spesifikasi aroma $N$. sithophila khas fermentasi sedangkan aroma T. viridae dengan aroma Apek. Produk fermentasi dari kapang $N$. sithophila lama inkubasi memberikan pengaruh terhadap aroma produk fermentasi semakin lama inkubasi menimbulkan aroma yang semakin khas yaitu wangi tape yang meningkat akan tetapi ada waktu maksimal. Sedangkan penggunaan $T$. viridae dengan lama inkubasi tidak terlalu berpenaruh terhadap aroma produk fermentasi yaitu berbau menyengat amoniak. Selama pertumbuhannya N sitophlla menghasilkan aroma alkohol atau ester pada produk akhir. Aroma dan warna produk fermentasi saling terkait serta juga menentukan kualitas fisik dari produk fermentasi. Hal tersebut juga di dukung oleh Cristi et al. (2018), yang menyatakan dimana warna yang baik akan menghasilkan pula aroma yang baik pula. Menurut Utomo (2010), menyatakan aroma pakan yang segar akan meningkatkan konsumsi oleh ternak. Sedangkan Widiyastuti et al. (2004), menjelaskan bahwa aroma dipengaruhi oleh kandungan lemak, protein dan kadar air pada pakan. Selama pertumbuhannya, N. sitophila menghasilkan gula sederhana, alkohol atau ester yang menghasilkan citarasa dan aroma pada produk akhir.

\section{Analisa Proksimat}

Uji Proksimat kandungan nutrisi dari produk fermentasi dari masing-masing perlakuan dapat dilihat Tabel 6. Dari data tersebut diperoleh data perlakuan yang memiliki kandungan protein tertinggi adalah perlakuan dengan kode A1B3 atau Kapang $N$. sitophila dengan lama inkubasi 8 hari dengan 
protein sebesar 26,13\%. kapang $N$. sitophila mampu menaikkan kandungan protein. Peningkatan protein kasar hasil fermentasi dapat akibat adanya pertumbuhan dan perkembangbiakan kapang $N$. sitophila yang subur dan merata. Dalam penelitian Melati et al. (2011), menjelaskan kenaikan protein pada proses fermentasi bisa disebabkan oleh pertumbuhan dan perkembangbiakan kapang.

\section{KESIMPULAN}

Ampas tahu hasil fermentasi $N$. sitophila selama delapan hari memberikan spesifikasi warna coklat, aroma khas fermentasi, dan tekstur yang kering. Kualitas nutrisi ampas tahu yang di fermentasi menggunakan kapang $N$. sitophila selama delapan hari dengan protein $26,13 \%$ memberikan kualitas lebih baik dibanding kapang $T$. viridae.

\section{DAFTAR PUSTAKA}

Achamadi, J. 2007. Kualitas pakan ternak yang baik dan aman untuk mendukung kesuksesan usaha peternakan. Universitas Diponegoro. Semarang.

Aisjah, T. 2001. Pengaruh takaran inokulum (T. viridae) dan suhu fermentor terhadap nilai gizi protein kasar dan serat kasar produk fermentasi bungkil kelapa sawit. Bionatura 3(3).

Beuchat, L. R. and L. R, B. 1977. Conversion of peanut shells and added nitrogen to protein by $T$. viridae.

Christi, R. F., Rochana, A. dan Hernaman, I. 2018. Kualitas fisik dan palatabilitas konsentrat fermentasi dalam ransum kambing perah peranakan Etawwa. Jurnal Ilmu Ternak. Universitas Padjajaran, 18(2): 121-125.

Hamelink, C. N., G. Van Hooijdonk, and A. P. C. Faaij. 2005. Ethanol from lignocellulosic biomasa, technoeconomic performance inshort, midleand long-term. Bimas and
Bionergy. 28: 384-410.

Judoamidjojo., M. Darwis, A. dan Sa'id, E. G. 1992. Teknologi fermentasi. Penerbit Rajawali pers, Jakarta.

Kanti, A. 2017. Potensi Kapang, Aspergillus niger, Rhizopus oryzae dan Neurospora sitophila. Buletin Peternakan, 41(1).

Leng, R. A. 1991. Application of Biotechnology to nutrition of animals in developing countries. F. A. O. Animal Production an Health.

Lestari, S. 2001. Pengaruh kadar ampas tahu yang difermentasi terhadap efisiensi pakan dan pertumbuhan ikan mas (Cyprinus carpio). Skripsi S1. Prodi Budidaya Peraiaran IPB, Bogor.

Melati, I., Mulyasari, M. dan Azwar, Z. I. 2011. Pengaruh fermentasi menggunakan Trichoderma viridae dan Phanerochaete chrysosporium serta gabungan keduanya terhadap komposisi nutrien tepung jagung sebagai bahan baku pakan ikan. Jurnal Riset Akuakultur, 7(1): 41-47.

Novianti, T., Wignyanto, W. and Nurika, I. 2012. Optimization spore producing $\beta$-karoten of fungus Neurospora sitophila by response surface method (On fermentatitation process duration and starter concentration). Jurnal Teknologi Pertanian, 5(2).

Noverina, N., Harlina, T., Yolandasari, D., Septianie, A., Nugraha, K., Dhalika, T. dan Budiman, A. 2008. Evaluasi nilai nutrisi tongkol jagung hasil bioproses kapang Neurospora sitophila dengan suplemtasi sulpur dan nitrogen. Jurnal Ilmu Ternak Universitas Padjajaran, $8(1)$.

Nurfaizin dan P. R. Matitaputty. 2015. Penggunaan kapang Karatogenik Neurospora sitophila dalam fermentasi limbah pertanian untuk pakan ternak ungas. Wartazoa 25(4): 189-196.

Sukarminah, E., Sumanti, D. M., dan Hanidah, I. 2008. Mikrobiologi 
Pangan. Bandung: Penerbit Jurusan Teknologi Industri Pangan. Universitas Padjajaran.

Telew, C., V. G. Kereh., I. M. Untu, dan B. W. Rembet. 2013. Pengayaan Nilai Nutrisi Sekam padi berbasis Bioteknologi "Effective Microorganisms" (EM4) sebagai bahan organik. Jurnal Zootek. 32(5).

Utomo, A. J. 2010. Palatabilitas seta rasio konsumsi pakan dan air minum kelinci jantan lokal peranakan New Zealand White yang diberi pelet atau silase ransum komplit. Institut Pertanian. Bogor. (Skripsi).

Pamungkas, F. B., sutrisno, E. dan sumiyati,S. 2011. Pengaruh variasi waktu fermentasi terhadap peningkatan protein pada apakn ternak dari campuran isi rumen sapi dan limbah kulit kopi dengan jamur T. viridae. (Doctoral disertation. Diponegoro University).

Purwati, C. S. dan Danang, R. 2018. Perubahan suhu, $\mathrm{pH}$, protein kasar, dan serat kasar pada fermentasi biji kecipir (Psophocarpus tetragonolobus) dan tepung jagung dengan level jamur Trichoderma viridae yang berbeda. J Ilmu dan Teknologi Peternakan Tropis, 5(3): 45-49.

Widiastuti, R. 2013. Kualitas pellet berbasis sisa Pangan Foodcourt dan Limbah sayuran fermentasi sebagai bahan pakan fungsional ayam broiler. Universitas Diponegoro, Semarang (Doctoral dissertation, Tesis). 